\title{
Nation-Building and Childhood in Early Twentieth Century Egypt ${ }^{1}$
}

\author{
Heidi Morrison \\ Introduction
}

In her autobiography, the Egyptian activist and writer Latifa Zayyat (1923-1996) recalls standing on the balcony of her home at 11 years of age and seeing the police shoot down 24 demonstrators. This was in 1934, when the Prime Minister, who served the King and the British Occupation, shut down all trains so that the leader of the majority Wafq party would not be able to tour the provinces. A procession of cars and thousands of people swarmed the streets. The municipality of the province ordered the digging of a series of trenches to prevent the demonstration from advancing. As Zayyat stood on the balcony, she counted the fallen bodies, observing guts exploding and deep red blood flowing like a waterfall. She noted one man raped by the policemen, while hearing her mother in the house cry. ${ }^{2}$

Writing many years later, Zayyat reflects on how she felt as a child watching the demonstration:

I find no refuge from the sense of powerlessness, of distress, or oppression that shakes me as the police shoot down twenty-four demonstrators that day, as I scream at my inability to do anything, to go down into the street and stop the bullets flying from the black guns. ${ }^{3}$

Although Zayyat saw herself as a helpless child in this moment of intense historic change, her life, and that of peers, was in reality at the heart of the Egyptian nationalist movement at the turn of the twentieth century. As we read further in Zayyat's autobiography, examples unfold of just how important children were to building the new Egyptian nation. Zayyat also recalls, for

\footnotetext{
1 Parts of this article are adapted from the author's book Childhood and Colonial Modernity in Egypt (New York: Palgrave Macmillan, 2015; reproduced with permission of Palgrave Macmillan).

2 Latifa Zayyat, The Search: Personal Papers (London: Quartet Books, 1996), 43.

3 Ibid., 42.
} 
example, many times in her childhood playing with her skipping rope on the rooftop while singing her favorite song: "Egypt, have no fear,/ This talk is all hot air./ We're the girl guides,/ Our father is Saad Pasha,/ Our mother is Safiyya Hanim."' Zayyat internalized patriotic songs that taught her the nation's heroes and encouraged her to be a mother of future citizens. She also learned in school that her success in life depended on a centralized Egyptian government. Zayyat says she was aware from the age of six onwards that Egyptians had to leave their villages and move to Cairo if they wanted higher education. ${ }^{5}$ While not directly fighting in the street battle, Zayyat was nonetheless engaged in a battle for the nation on her rooftop and in her school.

Egyptian nationalist reformers and intellectuals deliberately targeted the supple minds of children to create a new Egyptian nation independent from the British occupiers. Muhammad 'Abduh (1849-1905), for example, spoke to this goal when he claimed that the human spirit is like the earth because if it is not tended to and cultivated when it is tender then it will produce no results. ${ }^{6}$ During the early twentieth century, children were at the forefront of elite Egyptians' discourse and actions to build a state independent of the British, and to a lesser extent from the Ottomans. This resulted in a new conception of childhood, notably care for children became the responsibility of not just kin but outside experts. There was a synergistic relationship between the changing conception of childhood and the growing state apparatus. Such a fundamental shift in thinking set in place the development of large-scale institutions, such as public education, that remain in Egypt today. Although resembling the Western and Ottoman trajectories of modernization, the model of childhood that evolved in Egypt followed its own path. This chapter explores the theme of childhood in early twentieth-century Egypt through the work of Egyptian intellectuals and the Egyptian children's press.

\section{Common Childhoods}

Before exploring how the modern state apparatus entered Egyptian children's lives, it is useful to paint a picture of the typical network that shaped Egyptian childhoods during the nineteenth and early twentieth centuries. Generally, children's immediate and extended families prepared them for adulthood

4 Ibid., 17.

5 Ibid., 37 .

6 Muhammad 'Abduh, al-Islam wa-l-radd 'ala muntaqidihi (Cairo: Al-Maktaba al-Tijariyya alKubra, 1928), 165 . 
skills, leaving recreational activities to the children themselves. Adults believed that at around the age of seven, children developed 'aql, which is reason, maturity and the ability to learn. Adults did not throw children into the world of adults as soon as they developed ' $a q$ l but instead gradually introduced them to work, allocating time as well for some degree of studies and play.

In rural areas, adults largely believed that their children's futures were in the local surroundings, be it the land, household or artisan trades. Girls stayed at home until around the age of five, when they would then begin fetching water and helping their mothers with such work as cooking, cleaning and making fuel cakes. Boys also usually stayed home until the age of five, when they would then begin to take the donkeys to the field or the buffalo to the canal. At around eight years of age some girls might begin work as maids in a middle-class home, but most stayed at home to continue helping the family. Boys, on the other hand, might begin part-time religious schooling (in a kuttāb) while working in the fields. In their free time, boys would often wander past houses, calling out the names of their friends until a group formed for play on the land and in the canals. Play for girls was more limited than for boys because their opportunities for leaving the house were fewer and they were married at a young age. Both boys and girls often listened alongside adults to community storytellers, musicians and poets.

\section{Historical Backdrop}

In Egypt, the process of bringing children into the state fold began under Muhammad 'Ali (1769-1849) at the start of the nineteenth century. 'Ali attempted to create a dynasty separate from the Ottoman Empire, to which Egypt technically belonged. 'Ali sent missions to Europe to learn customs and habits (including those relating to offspring, marriage, games and sports) that could be transmitted to the Egyptian domicile, in hopes of modernizing the masses. ${ }^{7}$ He also secured a hereditary system of governance through total control of the military, which included conscription of children. ${ }^{8}$ 'Ali's reorganization of the Egyptian economy around long-staple cotton as a cash crop allowed him to secure a monopoly that locked peasant children into working for the state. 'Ali prohibited family migration to the cities, conscripted children laborers and

7 Lisa Pollard, "The Habits and Customs of Modernity: Egyptians in Europe and the Geography of Nineteenth-Century Nationalism," Arab Studies Journal, $7 / 8$ (2), 1999/2000, $5^{2-74 .}$

8 Khaled Fahmy, All the Pasha's Men: Mehmed Ali, His Army, and the Making of Modern Egypt (Cairo: American University in Cairo Press, 2002). 
ordered Egyptian peasants to cultivate cotton to the exclusion of all other crops, which he bought and then sold to British textile manufactures at a higher price.

'Ali's use of children to help build a nation was not unique in this century of budding nation-states. Around the world, leaders sought to help build the future of their nations by instituting changes in the lives of their littlest citizens. For example, during the partisan wars that broke out in Argentina after its independence from Spain in 1816, the Rosas regime assumed control in 1829 and moved aggressively to employ lower-class children, who were seen as a potential source of social disorder. In Japan, the Meiji leaders who took control in 1868 set out to create a centralized school system that would mobilize the people against an encroaching Western imperialism. In the nineteenth century climate of economic and imperial rivalry, the Ottoman Empire sought to hold on to its subjects through a series of centralizing state reforms targeted at children in the various provinces. The Ottoman Empire attempted to govern its diffuse populations by training more teachers and educators as agents of the state. ${ }^{9}$

The successors of Muhammad 'Ali continued to use children to build the Egyptian dynasty that he envisioned independent of the Ottomans. They did so by a continuation of his economic policies that interfered in the lives of the country's children. By the end of the nineteenth century, the single most common feature of most Egyptian childhoods was participation in the state cotton economy. ${ }^{10}$ Government primary schools for boys had operated in limited number since 1837 and for girls since 1873; however, the state made dismally low expenditures on education and continued the process of intervening in the lives of children by exploiting the Nile Valley to provide British mills with raw cotton. ${ }^{11}$

\section{Creating a New Child}

By the end of the nineteenth century, there existed a group of Egyptians who wanted an end to the Muhammad Ali dynasty, which they viewed as a puppet

9 Emine Evered, Empire and Education under the Ottomans: Politics, Reform and Resistance from the Tanzimat to the Young Turks (London: I. B. Tauris, 2012).

10 Ellis Goldberg, a political scientist, found that in Egypt during the period 1880-1950 the labor of children was the single largest input for the production of the country's cotton. Overall, the labor of boys accounted for nearly $35 \%$ of the total labor requirement for the major Egyptian crops, and they were mostly employed in cotton. See Ellis Goldberg, Trade, Reputation, and Child Labor in Twentieth-Century Egypt (New York: Palgrave Macmillan, 2004), 65.

11 Goldberg calculates that demand for the labor of children and the acquisition of literacy were inversely related. Ibid., 149 . 
for the recently established British protectorate in Egypt. These Egyptian nationalists, similar to the Young Turks, also refused to be part of a large Islamic umma, for which the Ottoman Empire was advocating to curb its looming demise. The first Egyptian nationalist groupings appeared in 1879, under the direction of Ahmad Urabi (1841-1911), due to dissatisfaction with Isma'il, the grandson of Muhammad 'Ali, and with European intruders. After the First World War, Sacd Zaghlul (1859-1927) and the Wafd party led the nationalist movement, culminating in the Revolution of 1919 and Britain's Unilateral Declaration of Egyptian Independence in 1922. However, Egypt did not really obtain full independence from the British until the military coup of 1952.

By the turn of the twentieth century, efforts by nationalist reformers and intellectuals to intervene in the lives of children to develop an independent Egypt were well underway. For instance, one year after Egypt transformed from a protectorate into a semi-autonomous state (1923), elementary education became compulsory for all Egyptian children, even though very few children actually attended. Taha Husayn (1889-1973), a leading intellectual and future Minister of Education, placed a large responsibility for effecting changes in child rearing onto the government. In his writings, Husayn articulates what exactly the government needs to address: teaching children the language, history and geography of Egypt and ensuring the development of the children's entire being. Learning how to think, be free and have peace, all aspects of a desired new citizenry, come from proper education whose goal is not just to get a job, nor only to teach literacy and mathematics:

If he [the young boy] grows up weak of mind, corrupt of opinion, malformed of thought, unable to understand and make judgment, ready to be influenced by everything that he encounters, and in compliance with everything that prevails upon him, he is dangerous to himself and his nation because he is dangerous to the social system. ${ }^{12}$

Husayn placed the responsibility of educating children on the state because he did not think the masses could be relied upon alone to educate the country; the government is obliged to provide education to its people because the people are not fit to do so themselves. ${ }^{13}$ Most Egyptian, he explains, are still completely ignorant and even the small percentage of Egyptians who are educated

\footnotetext{
12 Taha Husayn, Mustaqbal al-thaqafa fi Misr (Cairo: Matba'at al-Ma'arif wa-Maktabatuha, 1938), 108.

13 This is in addition to the fact that by this point the constitution made education compulsory.
} 
(he estimates this at $20 \%$ ) have been taught in either a religious or European fashion. ${ }^{14}$ One concrete way by which the government must ensure a proper education system, according to Husayn, is by ensuring teachers are properly trained and supported.

Nationalists wanted to bring children into the fold of the state through means such as education, raising a new generation of Egyptians skilled in modern knowledge and technology who would be strong enough to resist the British. The very first children's magazines to appear in Egypt were about teaching science and did not include any entertainment, humor or illustrations. Children's magazines thereafter were generally educational, teaching math skills or historical facts. Samir al-Tilmidh [Samir the Student], for example, published several articles on geography, such as the forests of Congo and winter climates in Nordic countries. ${ }^{15}$ Waladi [My Boy] also emphasized geography, running an ongoing column called "Around the World" about transportation, food, water and natural resources in different regions. ${ }^{16}$ Muhammad al-Harawi, a children's poet, produced several collections of poetry in the vein of teaching children their importance to the nation as future workers and professionals. In the introduction to one of his collections, entitled The New Child, he declares that the book's goal is to educate children on everything from how to properly greet visitors to how to count to how to give a speech.

It was not uncommon to find in the early twentieth-century Egyptian children's press photographs of children posed next to new technology, such as typewriters, automobiles, clocks, cameras, bicycles, telescopes, moving pictures and record players. What is most striking in all of these photos is the way in which the set-up of the scene by the photographer brings the viewer's focus onto the objects and not the child. It is as if the child were there only to show off his possession of or mastery over modern western technology. Whether the photo be of a record player on a table in the center of a room, with children's backs pushed up against encircling chairs, or of a motionless boy staring at a typewriter, the photos seem to say that the child is defined less by his/her relationship to the object than the presence of the object itself. The captions to the photos say nothing of the child's feelings about what he or she is doing, instead drawing attention to children's use of technology. This in turn conveys that childhood is valued not so much for the child him/herself but for the vessel of knowledge that the child represents for the future of Egypt.

\footnotetext{
14 Husayn, Mustaqbal al-thaqafa fi Misr, 71.

15 See, for example, the issues for May 1933 and January 1934.

16 For an example of an "Around the World" column focusing on China see Waladi, February 18, 1937.
} 
The rising Egyptian middle class, effendiya, fostered the idea of a new child skilled in modern knowledge and technology. Changing social class in Egypt was associated with displaying changes in one's ideas about childhood. Becoming effendi, or effendification, was a strategy and performance for people from lower-class urban and rural backgrounds who wanted to join the ranks of middle-income families in mid-level government professions such as teaching or the law. There was a synergistic relationship between these new professions and Egyptian nationalism: those who became upwardly mobile through education went on to engage in professions such as journalism that helped produce new ideas for the nation. ${ }^{17}$ As Lucie Ryzova observes, "[a] state-building project based on liberal ideology and institutions needs a middle class." 18

Another way to build the nation was to teach the children that they had a shared heritage. Perhaps this is most explicitly articulated in the words of one advice manual that tells children: "You must love this country as you love your father, mother, brothers, and sisters."19 This same message of collective belonging can be found throughout the bulk of children's literature, from the cover of the February 1934 issue of Samir al-Tilmidh, which features a picture of the Prince with an announcement of birthday wishes to him on behalf of all the readers, to the introduction to a translation by Kamil Kilani, a children's book writer, of a story about the Russian leader Boutros (Peter) the Great, in which readers are told that the story will provoke in them love of the nation. ${ }^{20}$ It is almost as if the King is presented to the child readers as their father, and the Prince as their brother.

In order to implant in children the feeling of solidarity, the press presented to children the nation not just as a family, but also as a family that was thousands of years old. In the children's press there are several references to the golden age of pharaonic times and Egypt's roots in ancient civilization. Harawi for example, wrote poems about the pyramids, the Sphinx, pharaonic holidays and the collection of antiquities held in Qasr al-Nil. The pyramids are described as the tombs of the old kings of Egypt and lauded for their indestructibility

17 Omnia El Shakry, The Great Social Laboratory (Stanford, CA: Stanford University Press, 2007), 16-18. Another example is Taha Husayn serving as Minister of Education.

18 Lucie Ryzova, "Egyptianizing Modernity through the 'New Effendiya," in Arthur Goldschmidt, Amy J. Johnson and Baraka A. Salmoni (eds), Re-Envisioning Egypt 1919-1952 (Cairo: American University in Cairo Press, 2005), 131.

19 Ahmad Afandi Salih, Kitab 'allimu al-atfal ma yaf'alunahu wa-hum rijal (Cairo: Al-Matba'a al-Amira, 1894), 22.

20 Samir al-Tilmidh, February, 1934, 1; Kamil Kilani, al-Malik al-Najjar (Cairo: Matbacat al-Ma'rifa, 1935), 1. 
through time, which is said to indicate that Egypt is the mother of work and science. The idea of Egypt existing as a cohesive community since the pharaonic ages is an invented idea. The process by which Egyptians came to call themselves Egyptian in the last few centuries required coercion of the people by its leaders for their own self-interest. ${ }^{21}$ As the historian Jamal Hamdan discusses in his four-volume study on the identity of Egypt, the building of Egyptian society has been based on both a continuation of old ways and an adoption of new ways through a series of many different occupiers (Persian, Roman, Greek, Mamluk, Ottoman, French and British). ${ }^{22}$ Answers to questions such as whether or not Egypt is pharaonic or African or Mediterranean or Arab have depended on the political climate of the time during which the questions were being asked. For the first half of the twentieth century the two main intellectual trends in Egypt regarding the country's identity consisted of (1) those who said Egyptian identity derives itself from its pharaonic, Mediterranean and Arab past and that this identity was neither purely secular nor purely Islamic; (2) and the Salafi movement, which said Egyptian identity derives from its Islamic past and that Western liberal ideas can be found in Islamic beliefs and practices.

Teaching children a cohesive national identity required the use of new gender roles. In 1900, Qasim Amin's book The New Woman heralded a new kind of woman in the Egyptian cultural scene: the new woman was supposed to be educated and to advance the nation by raising the moral and material level of the house. ${ }^{23}$ The goal of educating girls was to produce better domestic caregivers for future Egyptian generations. ${ }^{24}$ In 1905, a column entitled "[Which Education is more Influential: Education in the Home or in the School?]" appeared in al-Tarbiya [Upbringing], a magazine for teachers:

\footnotetext{
21 Fahmy, All the Pasha's Men.

22 Jamal Hamdan, Shakhsiyat Misr: Dirasa fi Abqariyat al-Makan, Volume 4 (Cairo: Dar al-Hilal, 1995), $55^{2}$.

23 Mona Russell, Creating the New Egyptian Woman: Consumerism, Education and National Identity, 1863-1922 (New York: Palgrave Macmillan, 2004).

24 Qasim Amin's previous book The Liberation of Women, published in 1899, was seminal-it argued that children are ignorant because mothers are ignorant. Both works have been published in English in a combined edition, Qasim Amin, The Liberation of Women and The New Woman: Two Documents in the History of Egyptian Feminism (Cairo: American University in Cairo Press, 200o, translated by Samiha Sidhom Peterson.). For more information on the role of mothers in early twentieth-century Egyptian society, see Omnia El Shakry, "Schooled Mothers and Structured Play: Child Rearing in Turn-of-the-Century Egypt," in Lila Abu-Lughod (ed.), Remaking Women: Feminism and Modernity in the Middle East (Princeton: Princeton University Press, 1998), 126-170.
} 
The family is the first school that is responsible for the youth's education at the outset. [...] Children that go on the wrong path and deviate were raised by ignorant, uneducated mothers and the roots of this badness will not be able to be changed later (in school). ${ }^{25}$

In the children's press, girls were not taught like boys to be warriors and leaders of the nation: in Kamil Kilani's two hundred-plus stories for children there are no female heroines and the female characters that appear are usually presented as prizes/rewards for the male heroes. Also, magazines that ran ongoing stories rarely used females as the main characters, or if they did it was in the role of being a homemaker. ${ }^{26}$

Girls' engagement in social, cultural and economic realms was defined as much by class as by gender. For example, the type of education offered to an upper/middle class girl in a state school was different from that for a lowerclass girl. The class-based curriculum meant that upper/middle class girls had additional opportunities to learn language, art, dance and piano. The reason for teaching upper/middle class girls these additional skills was so that they could be appropriate wives for the new effendi family. Children of the effendi class needed mothers who could stimulate them. effendi husbands needed engaging wives.

The idea also emerged that experts should play a role in not just supervizing the intellectual and mental development of children but also the physical. According to Husayn:

The state is not just responsible for building the mind of the child and his heart, but also is responsible for the protection of his body from diseases and providing him with steady growth that does not expose him to trouble and immorality. ${ }^{27}$

Husayn thus claims that if the Egyptian government cares for the children, then the country is guaranteed generations of people (i.e. a nation) healthy in body and mind. According to nationalist elites, play, for instance, was no longer to be left to the whims of the children alone. In 1905, al-Tarbiya also ran an article which defined the two types of exercise possible for children, spiritual

\footnotetext{
25 "[Which Education is more Influential: Education in the Home or in the School?]" al-Tarbiya, March 1, 1905, 10.

26 The magazine Waladi, run by a female editor, in 1937 published a piece on Joan of Arc, but the female heroine did not reappear and the title of the magazine itself meant "My Boy."

27 Husayn, Mustaqbal al-thaqafa fi Misr, 101.
} 
and material. The former included visiting old monuments, reading and listening to music, while the latter included walking and swimming. The article's stated purpose is to show the difference to children between activities that are for the mind and those that are for the body, and the ideal activities that combine both, such as billiards. Each edition of Waladi contained a column on exercises with illustrations on how to perform them. The column advises the child to do these exercises ten times per day before school. Waladi also contained a column entitled "[Come, Let's Play]," in which examples of children's games were explained, such as one in which children form a circle holding hands with one child in the middle who must escape. ${ }^{28}$ Not only were the types of exercise prescribed but so too were the times at which they should occur. Harawi published a poem called "[Sports and School]," encouraging children to play at specific intervals in between their lessons. ${ }^{29}$

Nations are formed through discipline and also attachment to an "imagined community."30 During the nineteenth and early twentieth centuries, segments of the Egyptian population were targets of the hegemonic state-building process: peasants, for building the army; ${ }^{31}$ mothers, for raising future citizens; ${ }^{32}$ middle class men, for strengthening national honor; ${ }^{33}$ and the poor, around whose needs politicians vied for power. ${ }^{34}$ The intrusion of outside experts in the rearing of children was essential for creating a nation. Foucault posits that society imposes through such institutions as the school a normalized type of behavior that children internalize. These institutions are in turn "architects of childhood." ${ }^{35}$ With the intervention of the state in the lives of children, reformers sought to create informed, skilled and loyal future citizens.

28 "[Come, Let's Play]," Waladī, February 18, 1937, 24.

29 Muhammad al-Harawi, "[Sports and School]," al-Tifl al-jadid, 1931, 38.

30 Benedict Anderson, Imagined Communities. New York: Verso, 2000.

31 Fahmy, All the Pasha's Men.

32 Lisa Pollard, "Learning Gendered Modernity: The Home, The Family and the Schoolroom in the Construction of Egyptian National Identity (1885-1919)." In Amira Sonbol (ed.), Beyond the Exotic: Women's Histories in Islamic Societies (NY: Syracuse University Press, 2005), 249-269.

33 Wilson Jacob, Working Out Egypt: Effendi Masculinity and Subject Formation in Colonial Modernity, 1870-1940 (Durham, NC: Duke University Press, 2011).

34 Mine Ener, Managing Egypt's Poor and the Politics of Benevolence, 1800-1952 (Princeton: Princeton University Press, 2003).

35 Mark A. Jones, Children as Treasures: Childhood and the Middle Class in Early Twentieth Century Japan (Cambridge, MA: Harvard University Press, 2010), 3. 


\section{Institutions}

According to nationalist elites, the parents and the village were no longer sufficient as the sole caregivers of children. Children needed the government and trained professionals. Nationalists claimed that it was out of moral obligation that the government and elites were stepping into the guardianship role hitherto played exclusively by parents, kin and community. The new concept of childhood that evolved in the first half of the twentieth century required institutions to implement it, and children's literature was one such institution. Children in Egypt had always been exposed to stories, but during the first half of the twentieth century classics, translations and new stories became more accessible to children through the creation of a children's press and through the encouragement of reading. ${ }^{36}$

The initial interest in Egypt in children's literature began with the Egyptian intellectual a Rifa'a Rafic al-Tahtawi, who brought the concept to Egypt from France at the beginning of the nineteenth century. Al-Tahtawi founded the first printing press in Egypt, Bulaq Printing Press, in 1824. However, large-scale children's literature did not begin until decades later, following improvements in technology, advancements in the science of bookmaking, and the changing concept of childhood. After the 1920s, when the children's press became a true commercial enterprise, it also began to include more and more translated foreign material. This was not just because of what the writers and editors wanted to teach children and what was cheaper to produce, but was also due what the readers wanted to buy. However, the foreign material used was often modified to fit local customs. For example, Mickey Mouse came to Egypt in 1936 and the translators appealed to local popular tradition by producing texts in the form of $a s j \bar{a}^{c}$ rhymed zajals and using dialect (and which did not fit into the speech bubbles). Tintin arrived in 1948, renamed Humhum and changed to a darker color. But Tintin did not use zajals and this marked the beginning of foreign texts being directly translated without adapting to local style (other than writing from right to left). Local artists and original work for children was revived at the end of the 1960 .

Several independent children's magazines existed at the start of the twentieth century addressing political, social and cultural themes. ${ }^{37}$ One

36 Also, mothers were taught in women's periodicals to encourage their children to read. See Margot Badran, Feminists, Islam, and the Nation: Gender and the Making of Modern Egypt (Princeton: Princeton University Press, 1995), 140.

37 For a full review of these magazines see Bertrand Millet, Samir, Mickey, Sindbad et les autres: Histoire de la presse enfantine en Égypte (Cairo: CEDEJ, 1987). 
magazine that is representative of the whole body of children's magazines was Baba Sadiq [Papa Sadik], launched in 1934 by Muhammad Sadiq 'Adb al-Rahman and which monopolized the children's press market until its disappearance in 1945. It had normative objectives and was almost entirely written in simple classical Arabic. It was published every two weeks and was 20 pages, with photos but few illustrations and no color. Each week the magazine showcased stories of traveling animals, for example the rabbit Chuchu who discovered many parts of the world. The magazine also had moralizing texts, a page of poetry, and contests, as well as a page dedicated just for girls. Portrait photos of young readers often decorated the front page, and the back page was dedicated to movie actors or singers (for example, Abd alWahhab was in the first edition in 1936). The magazine also ran advertisements for certain books and shops in Cairo and Alexandria. There were several pages dedicated to the King, especially after the death of King Fuad and the coronation of Faruq. The restrictions of the Second World War brought the magazine to a close.

New social welfare projects were another example of an institution through which outsiders became involved in the lives of children. Throughout Islamic history private groups and endowments ensured some kind of care for the poor. However, the social work done at the turn of the twentieth century was different in that its goal was to build the Egyptian nation. From the last decades of the nineteenth century through the first decades of the twentieth century, children appeared center stage in discourses on social assistance, public health and public safety in Egypt. ${ }^{38}$ In 1935, the Egyptian Congress created a program calling for the creation of village health and educational facilities and in 1936 Congress upgraded the Department of Public Health to the Ministry of Health; however, few programs were executed, for political and financial reasons. ${ }^{39}$ Community networks were being replaced by state agencies for dealing with issues such as premarital 'defloration' and child marriage. ${ }^{40}$

38 There was for all people a trend towards more government control over social services. See Ener, Managing Egypt's Poor; Lisa Pollard, Nurturing the Nation: The Family Politics of Modernizing, Colonizing, and Liberating Egypt 1805-1923 (Berkeley: University of California Press, 2005).

39 Nancy Gallagher, Egypt's Other Wars: Epidemics and the Politics of Public Health (Syracuse, NY: Syracuse University Press, 1990), 12.

40 For information on feminist efforts to create minimum marriage age laws in the personal status code see Badran, Feminists, Islam, and the Nation, 127-128. 


\section{Alongside the Western Model}

In the West, the most significant transition in the history of childhood is regarded as having occurred in the late nineteenth and early twentieth centuries: Hugh Cunningham identifies this period as being when the ideal of education and special protections for children spread to broad segments of the population. ${ }^{41}$ This chapter refrains from reducing the history of childhood in Egypt to a comparative one that holds modern Western standards of childhood as the model. Modernity was not a force emanating from the West and replicated by Egypt: although Egyptian intellectuals articulated similar ideals, particularly in regards to state intervention in the lives of children, they did so in a different framework. They did not adopt wholesale a Western model of childhood, but nor did they retreat to traditional extended family patterns as a form of refuge from and objection to western occupation. Egyptians carved out an identity that accepted, rejected and modified various aspects of modern European ideas.

Nationalist elites' ideas about childhood in the nineteenth and early twentieth centuries had three specifically Egyptian characteristics. First, Egyptian justifications and motivations for reforming childhood in Egypt emerged in large part from resistance to imperialism, which translated into Islamic heritage playing a role in shaping ideas towards childhood. During this period, Egyptian reactions to imperialism and the colonial gaze occurred on many levels of society, elite and non-elite. According to the historian Wilson Jacob: "The nature of colonial occupation was not only a matter of military and economic domination; it was equally and perhaps more insidiously a question of psychological domination." ${ }^{22}$ Colonizing Egypt required not only physical control of the country but also control of the inner, mental sphere of Egyptians. The belief that Egyptian parents preferred to have their children work in fields rather than attend schools is part of the general colonial ideology in which the British portrayed themselves as bearers of civilization. Western images of Egyptian children often stressed the irresponsibility of Egyptian child-rearing practices and conveyed the idea that the ragged condition of poor Egyptian children was due to moral and cultural decline. For example, a series of commercial slides produced by an American company in Egypt and distributed in the United States and Europe in 1896 shows a group of naked children sitting

\footnotetext{
41 Hugh Cunningham, Children and Childhood in Western Society since 1500 (Harlow: Pearson Longman, 2005). 
in the dirt in undeniable conditions of hardship. The caption reads: "Degenerate Egypt - Wretchedness of the People." The photo gives the impression that the Egyptian child is helpless and a victim of a backward culture that produces negligent mothers who bear hordes of children.

As noted above, the Salafi movement, which started in the mid-nineteenth century, held that Egyptian identity derives from its Islamic past and that western liberal ideas can be found in Islamic beliefs and practices. In their calls to reform child-rearing practices, Egyptian Salafi intellectuals drew on ideas about childhood from Islamic, Arab and Mediterranean heritage. For example, the intellectual 'Abdallah al-Nadim (1845-1896) argued that the form of upbringing which he advocates used to be a part of the East at a time when writers produced books on child rearing to bring children "from the lowest point of bestiality to the highest point of humanness." ${ }^{33}$ Just as European social sciences made the Egyptians passive objects of observation and classification, the Egyptian intellectual elite saw Egyptians as educable and able to move out of stagnation. As Ashis Nandy argues: "Colonialism colonizes minds in addition to bodies and it releases forces within the colonized societies to alter their cultural priorities once and for all." 44

Second, in addition to reforming childhood out of resistance to imperialism, of central concern in discussions by Egyptian nationalists in reforming childhood was providing children with a moral education. Egyptian ideas about childhood were closely linked to religion. Tahtawi, for instance, wrote that there are three ways in which children should be nourished: first, feed the body; second, feed morality; and third, feed the mind. If any one of these nutrients is lacking in a child, then the child will be incomplete as an adult. A great mind, according to Tahtawi, is nothing without great morals. Tahtawi illustrates this point by saying that a person, no matter how great their skills, will not be able to successfully debate another person if he has hubris. Two examples of good moral behavior, according to Tahtawi, are modesty and hard work. This is similar to Taha Husayn, who explained that a proper education is not just for getting a job, nor only for teaching literacy and mathematics:

If he [the young boy] grows up weak of mind, corrupt of opinion, malformed of thought, unable to understand and make judgment, ready to be influenced by everything that he encounters, and in compliance with 
everything that prevails upon him, he is dangerous to himself and his nation because he is dangerous to the social system. ${ }^{45}$

The focus on raising a moral child must be understood in the context of the Middle Eastern heritage of $a d a b$ literature. Muslims in the past were familiar with the concept of childhood as a distinct stage in the human life cycle and developed rules and methods of child rearing, education and medical-hygienic treatment to assist children in the gradual process of development. Adab literature dated from the medieval period and was part of a large body of literary sources - including medical and legal writings, collections of hadith and consolation treatises for bereaved parents - that showed the importance Muslims thinkers paid to childhood. Adab literature is a corpus of instructions on how to raise a child to be a man who possesses appropriate manners, morals, hygiene and comportment.

Third, intellectuals and reformers in Egypt, unlike their contemporaries in Europe, framed the actualization of the child's self (or, in other words, the fulfilment of the child's potential) as having the purpose of serving the community. Starting from the eighteenth century, liberal European social-science ideas on the child's self-actualization were disarticulated from religious instruction and based on the individual as a sovereign and autonomous subject. This emphasis on the individuality of the child is seen in the writings of John Locke and Jean-Jacques Rousseau, whose works on childhood played an important role in shaping European conceptions of childhood in the nineteenth century. As Cunningham notes: "The art of child-rearing became one of hearkening to Nature, giving free reign to growth, rather than bending twigs to a desired shape."46 In Egypt, however, intellectuals argued that teaching moral values in children would serve the rebirth of the whole community.

Changing the nation through reforming childhood was a widespread concern in this era. Egyptian nationalist elites integrated some of the new European ideas about childhood into their discourse, but with a unique twist: they asserted that their ideas originated in the Egyptian heritage, be it pharaonic, Mediterranean, Islamic or Arab. However, Egypt also resembled other countries in the Middle East that also articulated a new form of childhood in a local framework. For example, Fortna writes about state-led initiatives to modernize the late Ottoman Empire population by infusing imported western educational systems with moral content appropriate to the Islamic-Ottoman

45 Husayn, Mustaqbal al-thaqafa fi Misr, 108.

46 Cunningham, Children and Childhood, 59. 
context. ${ }^{47}$ Similarly, the Lebanese resisted the French colonial project by stressing their children were sons and daughters of Arab and Lebanese civilization. ${ }^{48}$ Ela Greenberg finds that the Islamic Girls' School in Mandatory Jerusalem disseminated nationalist ideas through a curriculum that combined the study of Arabic and Islam with secular academic subjects. ${ }^{49}$ These societies made the modernizing project both western and traditional, so as not to be implicated in the colonial system.

\section{Conclusion}

Egyptian nationalist reformers and intellectuals wrote and advocated for experts, primarily in the form of the state, to increase their reach into the lives of children, be it through such institutions as schools, social welfare projects or the children's press. For some children, childhood went from being primarily a private family affair to being a matter of concern to strangers. Nationalist elites communicated the idea that the household, extended family and local religious school were not sufficient to raise the next generation of Egyptians.

The goal of the experts was to build a future independent nation by preparing children to serve Egypt professionally and to hold the nation together by having a shared identity. The resulting change in childhood from being a matter almost exclusively for family to a matter of large importance to outside experts occurred in a context of shifting class and gender dynamics. The new ideas about childhood were particularly directed towards parents of the upper class whose children had access to education. The modern Egyptian model of childhood did not develop as a copy of the western model, but neither as one cut off from outside influences. Modern ideas about childhood were refashioned and renegotiated by Egyptians. This process was not uncommon in other formerly Ottoman territories of the era, including the seat of the old Empire itself: Turkey.

47 Benjamin C. Fortna, Imperial Classroom: Islam, the State, and Education in the Late Ottoman Empire (Oxford: Oxford University Press, 2002).

48 Taylor Long, "Political Parenting in Colonial Lebanon," Journal of the History of Childhood and Youth, 4 (2), 2011, 257-281.

49 Ela Greenberg, "Educating Muslim Girls in Mandatory Jerusalem," International Journal of Middle East Studies, 36 (1), 2004, 1-19. 


\section{Bibliography}

\section{Primary}

'Abduh, Muhammad, al-Islam wa-l-radd 'ala muntaqidihi, Cairo: Al-Maktaba al-Tijariyya al-Kubra, 1928.

Amin, Qasim, The Liberation of Women and The New Woman: Two Documents in the History of Egyptian Feminism, Cairo: American University in Cairo Press, 2000, translated by Samiha Sidhom Peterson.

"[Come, Let's Play]," Waladi, February 18, 1937, 24.

Harawī, Muhammad al-, "[Sports and School]," al-Tifl al-jadid, 1931, 38.

Husayn, Taha, Mustaqbal al-thaqafa fi Misr, Cairo: Matba'at al-Ma'arif wa-Maktabatuha, 1938.

Kilani, Kamil, al-Malik al-Najjar, Cairo: Matba'at al-Ma'rifa, 1935.

Nadim, 'Abdallah, article in al-Ustadh, August 24, 1892, 202.

Salih, Ahmad Afandi, Kitab 'allimu al-atfal ma yaf'alunahu wa-hum rijal, Cairo: Al-Matba'a al-Amira, 1894.

"[Which Education is more Influential: Education in the Home or in the School?]" alTarbiya, March 1, 1905, 10.

Zayyat, Latifa, The Search: Personal Papers. London: Quartet Books, 1996.

\section{Secondary}

Anderson, Benedict. Imagined Communities. New York: Verso, 2000.

Badran, Margot, Feminists, Islam, and the Nation: Gender and the Making of Modern Egypt, Princeton: Princeton University Press, 1995.

Cunningham, Hugh, Children and Childhood in Western Society since 1500, Harlow, UK: Pearson Longman, 2005.

El Shakry, Omnia, "Schooled Mothers and Structured Play: Child Rearing in Turn-ofthe-Century Egypt," in Lila Abu-Lughod (ed.), Remaking Women: Feminism and Modernity in the Middle East, Princeton: Princeton University Press, 1998, 126-170.

El Shakry, Omnia, The Great Social Laboratory, Stanford, CA: Stanford University Press, 2007.

Ener, Mine, Managing Egypt's Poor and the Politics of Benevolence, 1800-1952, Princeton: Princeton University Press, 2003.

Evered, Emine, Empire and Education under the Ottomans: Politics, Reform and Resistance from the Tanzimat to the Young Turks, London: I. B. Tauris, 2012.

Fahmy, Khaled, All the Pasha's Men: Mehmed Ali, His Army, and the Making of Modern Egypt, Cairo: American University in Cairo Press, 2002.

Fortna, Benjamin C., Imperial Classroom: Islam, the State, and Education in the Late Ottoman Empire, Oxford: Oxford University Press, 2002. 
Gallagher, Nancy, Egypt's Other Wars: Epidemics and the Politics of Public Health, Syracuse, NY: Syracuse University Press, 1990.

Goldberg, Ellis, Trade, Reputation, and Child Labor in Twentieth-century Egypt, New York: Palgrave Macmillan, 2004.

Greenberg, Ela, "Educating Muslim Girls in Mandatory Jerusalem," International Journal of Middle East Studies, 36 (1), 2004, 1-19.

Hamdan, Jamal, Shakhsiyat Misr: Dirasa fi Abqariyat al-Makan, Volume 4, Cairo: Dar al-Hilal, 1995 .

Jacob, Wilson, Working Out Egypt: Effendi Masculinity and Subject Formation in Colonial Modernity, 1870-1940, Durham, NC: Duke University Press, 2011.

Jones, Mark A., Children as Treasures: Childhood and the Middle Class in Early Twentieth Century Japan, Cambridge, MA: Harvard University Press, 2010.

Long, Taylor, "Political Parenting in Colonial Lebanon," Journal of the History of Childhood and Youth, 4 (2), 2011, 257-281.

Millet, Bertrand, Samir, Mickey, Sindbad et les autres: Histoire de la presse enfantine en Égypte, Cairo: CEDEJ, 1987.

Nandy, Ashis, The Intimate Enemy: Loss and Recovery of Self Under Colonialism, New Delhi: Oxford University Press, 1983.

Pollard, Lisa, "The Habits and Customs of Modernity: Egyptians in Europe and the Geography of Nineteenth-Century Nationalism," Arab Studies Journal, 7/8 (2), 1999/2000, 52-74.

Pollard, Lisa. "Learning Gendered Modernity:The Home, the Family and the Schoolroom in the Construction of Egyptian National Identity (1885-1919)." In Amira Sonbol (ed.), Beyond the Exotic: Women's Histories in Islamic Societies, Syracuse, NY: Syracuse University Press, 2005, 249-269.

Pollard, Lisa, Nurturing the Nation: The Family Politics of Modernizing, Colonizing, and Liberating Egypt 1805-1923, Berkeley: University of California Press, 2005.

Russell, Mona, Creating the New Egyptian Woman: Consumerism, Education and National Identity, 1863-1922, New York: Palgrave Macmillan, 2004.

Ryzova, Lucie, "Egyptianizing Modernity through the 'New Effendiya," in Arthur Goldschmidt, Amy J. Johnson and Baraka A. Salmoni (eds), Re-Envisioning Egypt 1919-1952, Cairo: American University in Cairo Press, 2005. 